\title{
RADIOCARBON DATING OF THE BRONZE AGE BONE PINS FROM EURASIAN STEPPE
}

\author{
NATALIA I. SHISHLINA ${ }^{1}$, JOHAN VAN DER PLICHT ${ }^{2,3}$ and ELYA P. ZAZOVSKAYA ${ }^{4}$ \\ ${ }^{1}$ State Historical museum, Moscow, Russia \\ ${ }^{2}$ Center for Isotope Research, Groningen University, Groningen, the Netherlands \\ ${ }^{3}$ Faculty of Archaeology, Leiden University, Leiden, the Netherlands \\ ${ }^{4}$ Institute of Geography, Russian Academy of Sciences, Moscow, Russia
}

Received 4 June 2010

Accepted 22 December 2010

\begin{abstract}
Bone catapult and hammer-headed pins played one of very specific roles in funerary offerings in the Bronze Age graves uncovered in the Eurasian Steppes and the North Caucasus. Scholars used different types of pins as key grave offerings for numerous chronological models. For the first time eight pins have been radiocarbon dated. ${ }^{14} \mathrm{C}$ dating of bone pins identified the catapult type pin as the earliest one. They marked the period of the Yamnaya culture formation. Then Yamnaya population produced hammer-headed pins which became very popular in other cultural environments and spread very quickly across the Steppe and the Caucasus during 2900-2650 cal BC. But according to radiocarbon dating bone pins almost disappeared after $2600 \mathrm{cal} \mathrm{BC}$.
\end{abstract}

Keywords: Bronze Age, Eurasian Steppe, radiocarbon dating, bone pins.

\section{INTRODUCTION}

Bone (horn) pins occupy a special place among accessories spread in the Steppe and North Caucasus areas (Fig. 1). They were dated to different archaeological cultures and several typologies of pins were proposed (Latynin, 1967; Safronov, 1973; Derzhavin, 1991; Kovaleva, 1991 and Gey, 2000). These typologies were based on differences in size, construction details as well as ornamentation. Usually typological classifications are used as key elements in constructing chronological and cultural models. Indeed, different types of pins, i.e. catapult-shaped, hammer-headed, crook-shaped, stem-shaped, nail-shaped pins, were spread in many cultures (Gey, 2000; Bratchenko, 2001 and Gak, 2005). Sets of such pins are treated as supra-cultural elements and are used to synchronize in time different groups of people living in various areas (Shishlina, 2008).

Gorodtsov (1915) dated back hammer-headed pins to the Catacomb culture whereas Kovaleva (1991) dated them back to the Yamnaya culture. On the other hand Latynin (1967) believed that hammer-headed pins were used by Yamnaya-Majkop population. Gey (2000) has suggested that such pins were common in the Black Sea area and the North Caucasus foothills among Novotitorovskaya, Early Catacomb, North Caucasus, Late Yamnaya population groups within wide chronological and spatial ranges. Several pins have been found in the Poltavka and Fatyan graves as well as the Kuro-Arax site in Georgia (they are dated to the final stages of the aforesaid cultures). Sherratt (1997) considered them among specific cultural features which link the northern Caucasus and the steppes into a single cultural zone.

Corresponding author: N.I. Shishlina

e-mail: nshishlina@mail.ru 


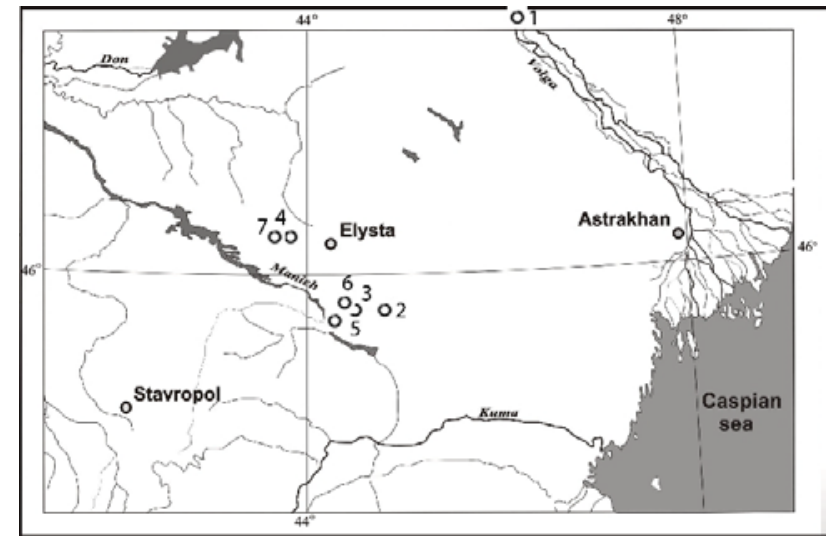

Fig. 1. Location of sites: 1 - Panitskoye $6 A ; 2$ - Mandjikiny-2; 3 - Mu-Sharet-I, 4 - Temrta V; 5 - Zunda-Tolga-5; 6 - Mu-Sharet-4; 7 - Sukhaya Termista II.

Catapult-shaped pins (Fig. 2: 5) appeared earlier than hammer-headed pins (Mimokhod, 2009). Hammerheaded pins with a straight stem decorated with horizontal cut lines and hatched stripes (Fig. 2: 7) are believed to be the earliest (Smirnov, 1996 and Kiyashko A, 1999). Pins decorated with geometric ornamentation (Fig. 2: 1, $3,4,6,8)$ are deemed to be the latest (Gey, 2000). Chronologically, non-decorated pins (Fig. 2: 2) may be placed in between these two groups. Pins of different types seem to have been in use in parallel both on the steppe and in the North-Caucasus areas. They are found in the same graves. Such coexistence is confirmed by kurgan stratigraphy, i.e. when a grave containing a pin of one type overlies another grave where a pin of a different type has been uncovered and vice versa. The type of the stem cannot be used as a strong classification attribute as the pins with the earliest ornamentation, i.e. horizontal lines, may have both a cylindrical and spindle-like stem. For example, hammer-headed pin with spindle-shaped stem decorated with horizontal lines from Sukhaya Termista I (Fig. 2: 7).

Therefore, the discussion about pins is centered on two major issues: (i) what culture/cultures they belonged to; and (ii) what time they are dated to, i.e. when they first appeared; how long they were used; the period to which the latest pins could be dated.

\section{The pilot project}

The largest number of pins has been found on the Caspian Steppes and in the Lower Don regions though people living in these regions were not the first and the only designers and users of such bone items. There are 221 pins and their fragments in the database which covers the North-West Caspian Steppes with the western part of the Middle Yergueni Hills (Rostovskaya oblast, Remontnensky region). The fragment of the pin which comes from the Repino grave located in the Saratov Volga region in Panitskoye 6B kurgan, excavation of R.A.
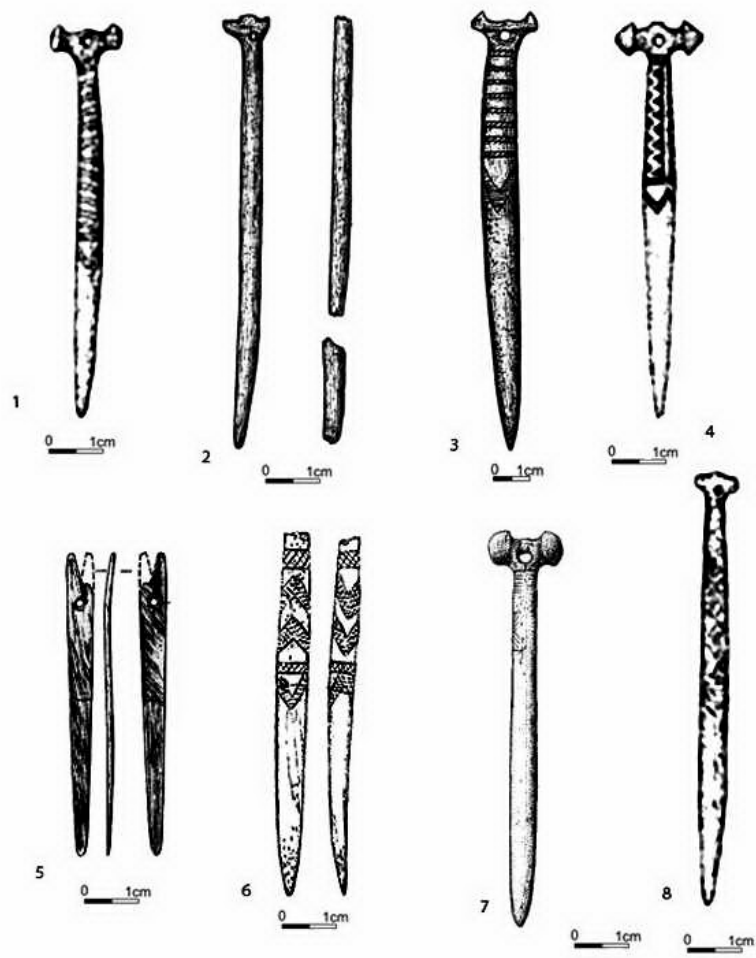

Fig. 2. Bone Pins: 1 - Mandjikiny-2, kurgan 1, grave 3, type 4, Yamnaya culture; 2 - Mu-Sharet I, kurgan 2, grave 3, type 2, Steppe North Caucasus culture; 3 - Mandjikiny-2, kurgan 54, grave 3, type 4, Early Catacomb culture; 4 - Temrta V, kurgan 1, grave 3, type 4, Early catacomb culture; 5 - Panitskoye 6A, kurgan 6, catapult-shaped, Repin culture; 6 - Mu-Sharet-4, kurgan 2, grave 1, type 4, Multicultural? (Early catacomb culture?); 7 - Sukhaya Termista II, kurgan 1, grave 11, type 1, Yamnaya culture; 8 - Zunda-Tolga-5, kurgan 1, grave 7, type 4, Yamnaya-catacomb culture.

Mimokhod, has also been used in the analysis (Mimokhod, 2009). The results of the cluster analysis of the Bronze Age graves of Kalmykia (Shishlina, 1992), and the study of Bronze Age cultures of the Caspian Steppe region (Shishlina, 2008) have shown that in many steppe Bronze Age cultures bone pins were used as funerary offerings together with other items for quite a long period. But relative chronology of pins does not show how long such pins were in use.

That is why the AMS radiocarbon dating of small fragments of pins of different types has been conducted. The pins subjected to this dating come from graves dating to different cultures (Fig. 3), which are located on the Caspian Steppes, the Lower Don region and the Volga region. Radiocarbon dating has been used to:

- Define when pins were first used as accessories;

- Determine how long these items were used;

- Specify possible cultural affiliation of the pins;

- Reveal correlation between relative chronology and absolute chronology of sets of pins.

It is very important to bear in mind the following two points. First, the dated fragments of the pins have been 


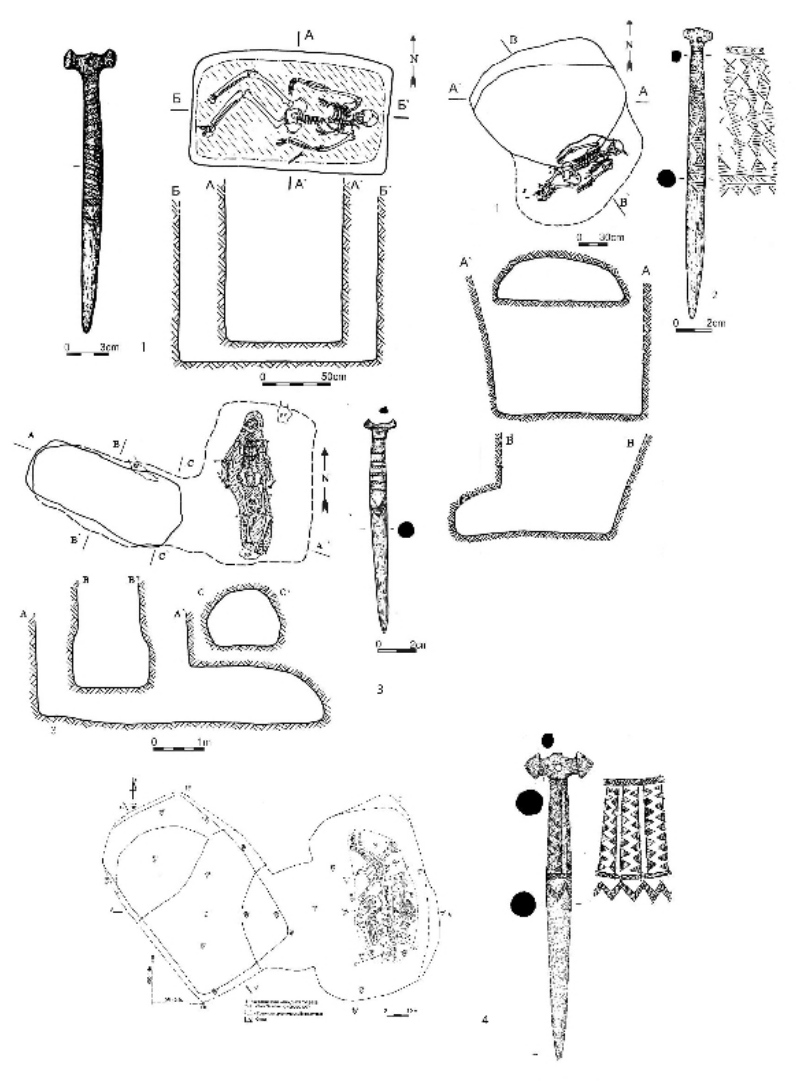

Fig. 3. Graves with hammer-headed bone pins: 1 - Mandjikiny-2, kurgan 11, grave 3, Yamnaya culture; 2 - Zunda-Tolga-5, kurgan 1, grave 7, Yamnaya-Catacomb culture; 3 - Mandjikiny-2, kurgan 54, grave 3, Early Catacomb culture; 4 - Temrta-V, kurgan 1, grave 3, Early Catacomb culture

found in a relatively small area of the Eurasian Steppes (Fig. 1) in graves dating to different cultures. That is why, the results reflect only temporal patterns of pin use in the area in question, while pins of various types could have appeared much earlier (e.g. in the Kuban region) or could have been in use much later (e.g. in the Fatyan and Kuro-Arax cultures) outside this area. Second, each of the item analyzed can have several dates (Harris, 1979):

- the date of the item origin;

- the interval of the item use;

- the date when the item was placed inside a closed archeological complex, i.e. the grave in our case.

\section{THE CULTURAL CONTEXT AND RELATIVE CHRONOLOGY}

As has been noted earlier, 221 bone/horn pins have been uncovered in the graves under discussion, with the total number of graves exceeding 1200. The elaboration of a new typology of bone pins goes beyond this project. Traditional types are used. The main characteristics of such types were proposed by Gey (2000), i.e. the shape and the absence or presence of decoration. Four types of hammer-headed pins have been singled out: type 1: pins with a cylindrical stem, a hammer-headed head and zonal ornamentation made of horizontal lines, or stripes (Fig. 2: 7); type 2: pins with a thin stem, a hammerheaded head, without ornamentation (Fig. 2: 2); type 3: pins with a large cylindrical stem, a hammer-headed head without ornamentation; type 4: pins with a spindle-like stem, a hammer-headed head, decorated by different variation of geometric ornamentation (Fig. 2: 3-4, 6, 8) (hatched triangles and stripes; hatched zigzags and rhombs and other compositions) (Shishlina, 2008).

Relative chronology of cultures to which discovered pins are attributed may be presented as follows: catapultshaped pins are considered to be the earliest pins, and precede the main types, i.e. hammer-headed pins (Kiyashko, 1992; Morgunova, 2006 and Mimokhod, 2009). Such pins have been found in the Repin and Early Yamnaya culture graves of Lower Don (Kiyashko, 2001), Kuban (Kozyumenko et al., 2001), the Lower Volga (Mimokhod, 2009), and the Ural regions (Morgunova, 2006), though few in numbers.

Bone hammer-headed pins of different types have been found in Yamnaya (Fig. 3: 1), Steppe North Caucasus, Early Catacomb (Fig. 3: 3, 4), Yamnaya-Catacomb (Fig. 3: 2) and Multi-cultural graves (Shishlina, 2008). According to the stratigraphic position of the pincontaining graves, the earliest pins were used by the Yamnaya population, but then such pins spread quickly beyond it and were a common funeral item in other cultures for quite a long period of time. The absence of hammer-headed pins of type 1 and 2 in the Early Catacomb and North Caucasus graves indicates that they had been used before other types appeared in Yamnaya graves. The latest hammer-headed pins have been uncovered in the multi-cultural graves. It is confirmed by stratigraphic data. In general, main types are standardized though numerous modifications of the main types are known, especially variations in ornamentation.

Other types of bone pins, i.e. stem-shaped, crookshaped and others were spread in Early Catacomb cultures (Shishlina, 2008).

Table 1. The distribution of bone pins in the Caspian Steppe Bronze Age cultures.

\begin{tabular}{lcccc}
\hline Culture & $\begin{array}{c}\text { Total } \\
\text { number of } \\
\text { graves }\end{array}$ & $\begin{array}{c}\text { Total } \\
\text { number of } \\
\text { graves with } \\
\text { pins }\end{array}$ & $\begin{array}{c}\text { Total } \\
\text { number of } \\
\text { pins }\end{array}$ & $\begin{array}{c}\text { Culture } \\
\text { time- } \\
\text { interval } \\
\text { (cal BC) }\end{array}$ \\
\hline Yamnaya & 733 & 73 & 126 & $3000-2500$ \\
\hline $\begin{array}{l}\text { Early } \\
\text { Catacomb }\end{array}$ & 190 & 40 & 61 & $2700-2400$ \\
\hline $\begin{array}{l}\text { Yamnaya- } \\
\text { Catacomb }\end{array}$ & 15 & 95 & 20 & $2600-2300$ \\
$\begin{array}{l}\text { Steppe North } \\
\text { Caucasus }\end{array}$ & 149 & 10 & 10 & $2500-2300$ \\
\hline Multi-cultural & 29 & 3 & 3 & $2500-2400$ \\
\hline
\end{tabular}


The distribution of bone pins in different cultures is shown in Table 1. Pins have been discovered in one out of ten Yamnaya graves, in one out of four Early Catacomb graves and in one out of six Yamnaya-Catacomb graves. The distribution of the pins in the Steppe North Caucasus and Multi-cultural groups is the following: one out of 15 graves and one out of 10 graves. For comparison see the distribution of pins in the Yamnaya UralMiddle Volga culture, i.e. pins have been discovered in 7 graves out of 250 , which means in one out of 35 graves (Morgunova, 2006).

\section{3. ${ }^{14}$ C DATING}

Ten micro-samples have been drawn for radiocarbon dating from Repin, Yamnaya, Early Catacomb, Steppe North Caucasus, Yamnaya-Catacomb and Multi-cultural groups. There was no collagen in the two samples. (Table 2, Figs. 2 and 3). The ${ }^{14} \mathrm{C}$ dates are calibrated using the CALIB REV6.0.0 program (http://calib.qub.ac.uk) and the IntCal09 data set (Reimer et al., 2009).

\section{DISCUSSION}

The earliest date is the ${ }^{14} \mathrm{C}$ date of a catapult-shaped pin (Fig. 2: 5) that comes from a Repin grave at Panitskoye 6A (Mimokhod, 2009). The pot of the Repin type has been discovered in the same grave. Two more radiocarbon dates of humans from the same grave have been obtained as well. The date obtained on bones of the male correlates with the date of the bone pin $(4500 \pm 120)$ (Fig. 4).

These two dates help us identify the time of pin emergence as 3200-3100 cal BC. While the author of the excavation believes the clay pot from Panitskoye $6 \mathrm{~A}$ to be a later imitation of the Khvalynsk-Berezhnovka ceramic tradition (Mimokhod, 2009), offerings from the grave in question are deemed to be much younger than the goods obtained from Khvalynsk burials, with the radiocarbon dates of the latter pointing to the time interval for Khvalynsk I and II cemeteries as $4400-4300$ cal BC (Shishlina et al., 2009). The time interval for the Steppe Eneolithic culture is 4300-3800 cal BC (Shishlina, 2008). Analyzing human remains from the Panitskoye grave,

Table 2. AMS dates of bone (horn) catapult-shaped and hammer-headed pins.

\begin{tabular}{|c|c|c|c|c|c|}
\hline Lab. No. & Kurgan/grave/culture/ type of pin & $\begin{array}{l}{ }^{14} \mathrm{C} \text { age } \\
\text { (BP) }\end{array}$ & $\begin{array}{c}\text { Calibrated age range } 1 \sigma \\
(y \mathrm{BC})\end{array}$ & $\begin{array}{l}\delta^{13} \mathrm{C} \\
(\%)\end{array}$ & $\begin{array}{l}\delta^{15} \mathrm{~N} \\
(\% 0)\end{array}$ \\
\hline GrA-45041 & $\begin{array}{l}\text { Panitskoye 6A, g. } 6 \\
\text { Repin } \\
\text { (Early Yamnaya) culture } \\
\text { catapult-shaped pin } \\
\end{array}$ & $4540 \pm 35$ & $\begin{array}{l}3361-3326,0.29 \\
3232-3224,0.04 \\
3219-3174,0.36 \\
3160-3119,0.31\end{array}$ & -19.42 & $\mathrm{n} / \mathrm{a}$ \\
\hline GrA-39349 & $\begin{array}{l}\text { Mandjikiny-2, k.11, g. } 3 \\
\text { Yamnaya culture } \\
\text { hammer-headed pin of type } 4\end{array}$ & $4320 \pm 60$ & $\begin{array}{l}3325-3233,0.35 \\
3223-3220,0.01 \\
3173-3161,0.04 \\
3118-3009,0.45 \\
2984-2934,0.15\end{array}$ & -17.85 & $\mathrm{n} / \mathrm{a}$ \\
\hline GrA-45036 & $\begin{array}{l}\text { Sukhaya Termista II, k.1, g.11 } \\
\text { Yamnaya culture } \\
\text { hammer-headed pin of type } 1\end{array}$ & $4150 \pm 30$ & $\begin{array}{l}2867-2836,0.22 \\
2816-2803,0.08 \\
2777-2670,0.70\end{array}$ & -19.91 & +5.75 \\
\hline GrA-35809 & $\begin{array}{l}\text { Mandjikiny-2 } \\
\text { k.54, g.6 } \\
\text { Early Catacomb culture } \\
\text { hammer-headed pin of type } 4\end{array}$ & $4135 \pm 35$ & $\begin{array}{l}2862-2831,0.18 \\
2821-2807,0.09 \\
2758-2718,0.26 \\
2707-2631,0.47 \\
\end{array}$ & -18.77 & $\mathrm{n} / \mathrm{a}$ \\
\hline GrA-30051 & $\begin{array}{l}\text { Temrta V } \\
\text { k.1, g.2 } \\
\text { Early Catacomb culture } \\
\text { hammer-headed pin of type } 4\end{array}$ & $4110 \pm 45$ & $\begin{array}{l}2856-2812,0.25 \\
2747-2725,0.12 \\
2698-2617,0.48 \\
2610-2581,0.15 \\
\end{array}$ & -18.28 & +8.75 \\
\hline GrA-42168 & $\begin{array}{l}\text { Mu-Sharet-1. k.2, g.3 } \\
\text { Steppe North Caucasus culture } \\
\text { hammer-headed pin of type } 2\end{array}$ & $4185 \pm 35$ & $\begin{array}{l}2920-2865,0.73 \\
2805-2760,0.27\end{array}$ & -20.20 & $\mathrm{n} / \mathrm{a}$ \\
\hline GrA-39717 & $\begin{array}{l}\text { Mu-Sharet-4, k.2, g.1 Early Catacomb? } \\
\text { (Multi-cultural?) culture } \\
\text { hammer-headed pin of type } 4\end{array}$ & $4190 \pm 70$ & $\begin{array}{l}3022-2861,0.77 \\
2808-2756,0.18 \\
2719-2704,0.05\end{array}$ & -19.61 & $\mathrm{n} / \mathrm{a}$ \\
\hline GrA -29135 & $\begin{array}{l}\text { Zunda-Tolga- } 5, \mathrm{k} .1, \mathrm{~g} .7 \\
\text { Yamnaya-Catacomb culture } \\
\text { hammer-headed pin of type } 4\end{array}$ & $4110 \pm 45$ & $\begin{array}{l}2856-2812,0.25 \\
2747-2725,0.12 \\
2698-2617,0.48 \\
2610-2581,0.15\end{array}$ & -21.01 & +5.36 \\
\hline
\end{tabular}


Khokhlov suggests that the male cranium belongs to the Yamnaya steppe group of the Volga region (Mimokhod, 2009).

Catapult-shaped pins or bone catapults of different modifications with or without ornamentation appeared in Early Yamnaya and Repin culture graves among other grave offerings. Such graves are localized at the North Caucasus Foothills and in the Asov Sea region, they are found on fewer occasions in the Lower Volga and the Ural regions (Tkachev, 2000). For example, a bone pin with horizontal ornamentation used as a part of a necklace made of perforated river shells has been found together with two catapult-shaped pins at Kavkazsky 2, kurgan 7, grave 9 (Kozyumenko et al., 2001). Grave offerings at Gerasimovka II, kurgan 4, grave 2, include a clay pot of the Repin type, a copper knife and clips as well as catapult-shaped pins. Two skulls were buried nearby (Porokhova, 1992).

The next date is the ${ }^{14} \mathrm{C}$ date of a hammer-headed pin found at Mandjikiny (Fig. 2: 1). It is a typical Yamnaya culture grave (Fig. 3: 1) made in a rectangular pit roofed with wooden boards. An adult female lying in a contracted supine posture was placed on its bottom. The ${ }^{14} \mathrm{C}$ date of the pin raises two issues. First, the date, i.e. $3000 \mathrm{cal}$ $\mathrm{BC}$, is rather early for a pin which, according to the proposed classification, should be attributed to type 4 . The pin has a straight stem and geometrical ornamentation. But according to the ${ }^{14} \mathrm{C}$ date, chronologically pins of such type should follow right after catapult-shaped pins. Two more ${ }^{14} \mathrm{C}$ dates have been obtained for the same grave, namely wood and human (female) bones (Table 3 , Fig. 5).

These two dates show that the grave should be dated to the time interval, which is 260 years later than the time of the bone pin production (Table 3 ). It is assumed that in all cultures pins were used for a long time. Some pins have broken heads, but apparently people did not throw them away. Broken hammers or stems were polished, an additional hole could be perforated in the stem (for example, Vostochny Manych, Left Bank II, 66, kurgan 35, grave 1), or pins with one of the hammer missing could be placed inside the grave (for example, Vostochny Manych, Left Bank II, 66, kurgan 30, grave 1). It implies that a lot of time could have passed between the time when the pin was made and the time when it was placed inside the grave. An expensive pin remained a very valuable item and was handed over from generation to generation. The last owner of the pin in question was a very old woman. Hence, this accessory was in use for more than 200 years. At least, radiocarbon dates obtained point to this fact.

Another type of bone pins with a straight cylindrical stem and ornamentation in the form of seven parallel crosslines and a two-part ornamental frieze covered by diagonal parallel lines located below can be attributed to type 1 , which is considered to be the earliest type of bone hammer-headed pins (Fig. 2: 7). However, according to

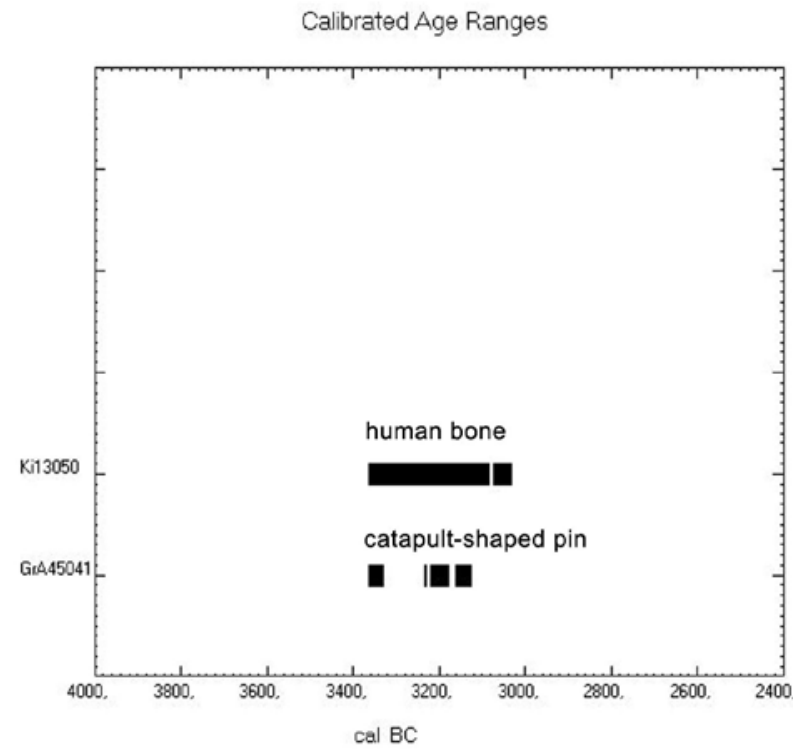

Fig. 4. Panitskoye 6A. Paired radiocarbon age of the catapult-shaped pin and human bone.

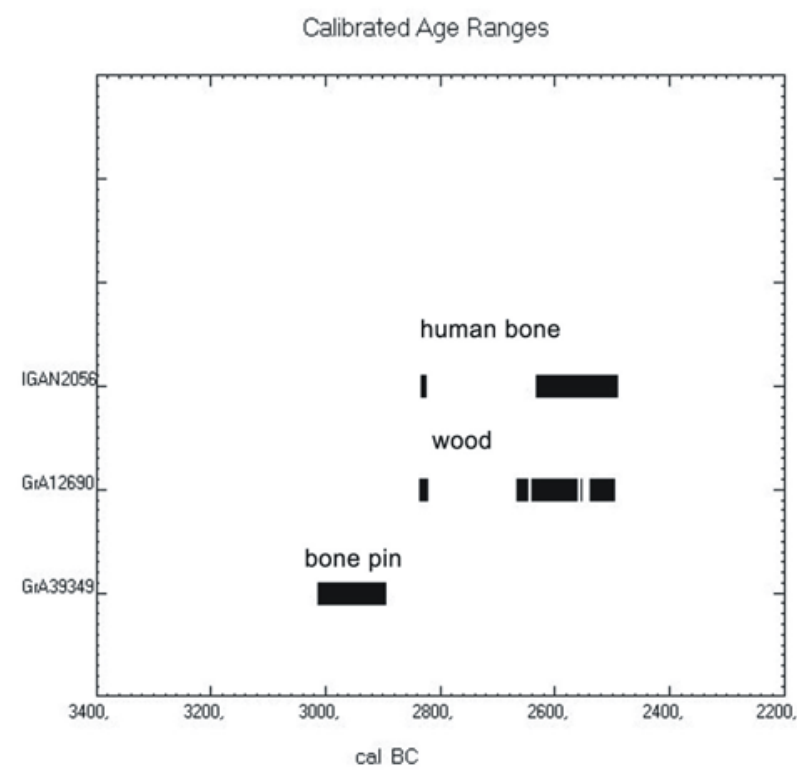

Fig. 5. Mandjikiny-2, kurgan 11, grave 3. Paired radiocarbon dates of hammer-headed pin, wood and human bone samples.

${ }^{14} \mathrm{C}$ date obtained, the pin from Sukhaya Termista II, kurgan 1, grave 11 was made around 2800 cal BC, it belonged to a young woman of 25 years for a short period (Fig. 6). When the woman died, the pin was placed inside her grave.

The next ${ }^{14} \mathrm{C}$ date is that of a pin of type 2, i.e. a pin with a thin stem without ornamentation uncovered in the Steppe North Caucasus grave at Mu-Sharet I, kurgan 2, grave 3 (Fig. 2: 2). Such pins are typical for the Yamnaya culture and they are found in other culture graves quite rarely. The date obtained points to the interval $3000-2800$ 
Table 3. Paired dates of samples from the same graves

\begin{tabular}{|c|c|c|c|c|c|c|}
\hline Lab. No. & Kurgan/grave/culture & Sample & $\begin{array}{l}{ }^{14} \mathrm{C} \text { age } \\
\text { (yr BP) }\end{array}$ & $\begin{array}{c}\text { Calibrated age range } \\
\text { (yr BC) }\end{array}$ & $\delta^{13} \mathrm{C}(\%)$ & $\overline{\delta^{15} \mathrm{~N}(\% 0)}$ \\
\hline GrA-45041 & $\begin{array}{l}\text { Panitskoye } 6 \mathrm{~A} \text {, grave } 6 \\
\text { Repin }\end{array}$ & Horn bone & $4540 \pm 35$ & $\begin{array}{l}3361-3326.0 .29 \\
3232-3224.0 .04 \\
3219-3174.0 .36 \\
3160-3119.0 .31\end{array}$ & -19.42 & n/a \\
\hline Ki-13050, & $\begin{array}{l}\text { Panitskoye } 6 \mathrm{~A} \text {, grave } 6 \\
\text { Repin }\end{array}$ & Male bone & $4500 \pm 120$ & $\begin{array}{l}3363-3078.0 .87 \\
3072-3024.0 .13\end{array}$ & n/a & $\mathrm{n} / \mathrm{a}$ \\
\hline GrA-39349 & $\begin{array}{l}\text { Mandjikiny-2, k.11, g. } 3 \\
\text { Yamnaya }\end{array}$ & Bone pin & $4320 \pm 60$ & $\begin{array}{l}3325-3233.0 .35 \\
3223-3220.0 .01 \\
3173-3161.0 .04 \\
3118-3009.0 .45 \\
2984-2934.0 .16\end{array}$ & -17.85 & n/a \\
\hline GrA-12690 & $\begin{array}{l}\text { Mandjikiny-2, k.11, g. } 3 \\
\text { Yamnaya }\end{array}$ & wood & $4060 \pm 50$ & $\begin{array}{l}2835-2817,0.10 \\
2665-2644,0.10 \\
2639-2557,0.52 \\
2555-2550,0.03 \\
2537-2491,0.27\end{array}$ & -24.33 & n/a \\
\hline IGAN-2056 & $\begin{array}{l}\text { Mandjikiny-2, k.11, g. } 3 \\
\text { Yamnaya }\end{array}$ & female bone $45-60$ & $4050 \pm 50$ & $\begin{array}{l}2832-2820,0.06 \\
2657-2655,0.01 \\
2632-2488,0.93\end{array}$ & $n / a$ & $\mathrm{n} / \mathrm{a}$ \\
\hline GrA-45036 & $\begin{array}{l}\text { Sukhaya Termista II, k.1, g.11 } \\
\text { Yamnaya }\end{array}$ & bone pin & $4150 \pm 30$ & $\begin{array}{l}2867-2836,0.22 \\
2816-2803,0.08 \\
2777-2670,0.70\end{array}$ & -19.91 & +5.75 \\
\hline GrA-45038 & $\begin{array}{l}\text { Sukhaya Termista II, k.1, g.11 } \\
\text { Yamnaya }\end{array}$ & female bone $25-30$ & $4160 \pm 30$ & $\begin{array}{l}2872-2848,0.16 \\
2842-2841,0.01 \\
2813-2798,0.11 \\
2794-2740,0.38 \\
2731-2693,0.28 \\
2688-2679,0.06\end{array}$ & -15.72 & +16.46 \\
\hline GrA-35809 & $\begin{array}{l}\text { Mandjikiny-2, k. 54, g. } 6 \\
\text { Early Catacomb }\end{array}$ & Bone pin & $4135 \pm 35$ & $\begin{array}{l}2862-2831,0.18 \\
2821-2807,0.09 \\
2758-2718,0.26 \\
2707-2631,0.47\end{array}$ & -18.77 & n/a \\
\hline IGAN -2277 & $\begin{array}{l}\text { Mandjjkiny-2, k. 54, g. } 6 \\
\text { Early Catacomb }\end{array}$ & Female bone $25-35$ & $4319 \pm 40$ & $\begin{array}{l}3010-2980,0.28 \\
2957-2952,0.03 \\
2940-2891,0.68 \\
\end{array}$ & -17.58 & +15.042 \\
\hline GrA -30051 & $\begin{array}{l}\text { Temrta V } \\
\text { k.1, g.2 } \\
\text { Early Catacomb }\end{array}$ & bone pin & $4110 \pm 45$ & $\begin{array}{l}2856-2812,0.25 \\
2747-2725,0.12 \\
2698-2617,0.48 \\
2610-2581,0.15\end{array}$ & -18.28 & +8.75 \\
\hline IGAN-3414 & $\begin{array}{l}\text { Temrta V } \\
\text { k.1, g.2 } \\
\text { Early Catacomb }\end{array}$ & female bone $20-25$ & $4333 \pm 80$ & $\begin{array}{l}3088-3058,0.12 \\
3030-2885,0.88\end{array}$ & $-17,97$ & $+12,49$ \\
\hline GrA-32893 & $\begin{array}{l}\text { Temrta V } \\
\text { k.1, g.3 } \\
\text { Early Catacomb }\end{array}$ & sheep bone & $4110 \pm 35$ & $\begin{array}{l}2852-2812,0.26 \\
2744-2726,0.10 \\
2696-2618,0.52 \\
2608-2598,0.06 \\
2594-2583,0.06\end{array}$ & -18.60 & +8.24 \\
\hline GrA -29135 & $\begin{array}{l}\text { Zunda-Tolga-5, k.1, g.7 } \\
\text { Yamnaya-Catacomb }\end{array}$ & bone pin & $4110 \pm 45$ & $\begin{array}{l}2856-2812,0.25 \\
2747-2725,0.12 \\
2698-2617,0.48 \\
2610-2581,0.15 \\
\end{array}$ & -21.01 & +5.36 \\
\hline IGAN -2494 & $\begin{array}{l}\text { Zunda-Tolga-5, k.1, g.7 } \\
\text { Yamnaya-Catacomb }\end{array}$ & female bone $50-55$ & $4866 \pm 60$ & $\begin{array}{l}3708-3632,0.86 \\
3558-3538,0.13 \\
\end{array}$ & -17.77 & +14.93 \\
\hline
\end{tabular}


cal BC. It was the time when there were no North Caucasus people on the steppes yet. Maybe, these two pins and one fragment (which was dated) of type 2 were placed into the grave much later than the time they had been produced.

Group 4 includes remaining four ${ }^{14} \mathrm{C}$ dates obtained for pins of different types. They have been uncovered in Early Catacomb (Fig. 3: 3, 4), Yamnaya-Catacomb (Fig. 3: 2) and Multi-cultural graves. Four pins can be attributed to type 4 (Fig. 2: 3, 4, 6, 8), which is characterized by a cigar-shaped stem decorated with geometrical figures such as hatched stripes, rhombs, triangles framed below by a belt with triangles. According to Gey (2000) classification, such pins date back to the latest type and were in use until the end of $3000 \mathrm{BC}$. Hence, these three pins practically fall within the same chronological horizon. We can assume that pins of this type were widespread around 2800-2600 cal BC. A "model pattern pin" was copied and subsequently rolled out throughout a local multi-cultural environment. Different variations of the same type were in use in parallel. The ${ }^{14} \mathrm{C}$ date of a Multi-cultural grave at Mu-Sharet-4, k.2, g.1, is a little bit older than the others, $2900-2800 \mathrm{cal}$ BC. We believe that the ${ }^{14} \mathrm{C}$ date indicates the time of the item origin; the pin itself was placed into the grave much later. It was broken but was not thrown away and was still used. Maybe such ${ }^{14} \mathrm{C}$ date will help us specify the cultural attribution of the grave, which probably does not belong to the Multicultural group but may be attributed to the Early Catacomb culture (Shishlina, 2008).

${ }^{14} \mathrm{C}$ data obtained for bone pins are useful for discussion of the reservoir effect correction. Almost all dates of human bones show the apparent age (Plicht et al., 2007 and Shishlina et al., 2009). Table 3 shows that there is no

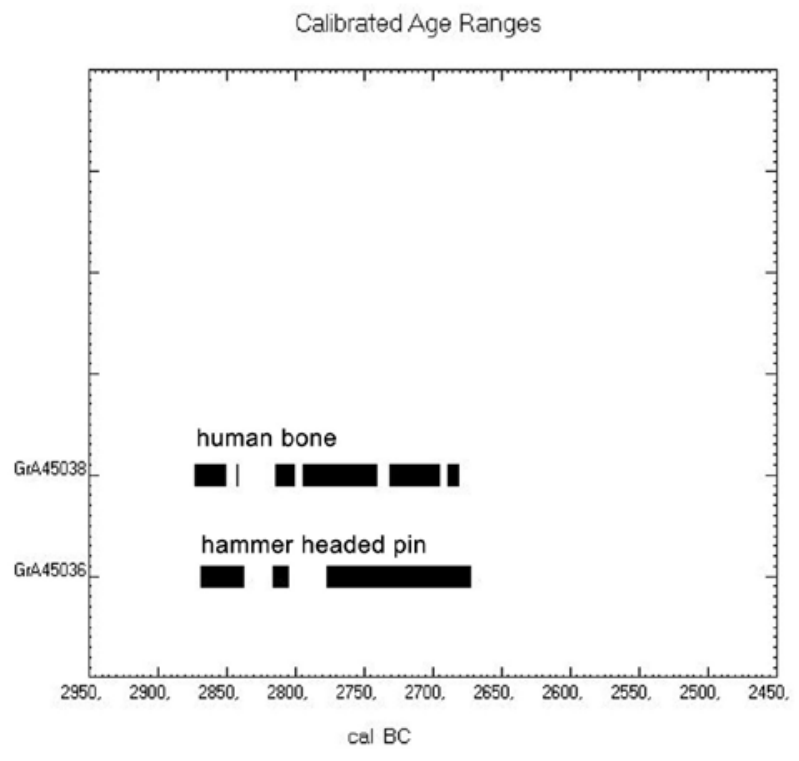

Fig. 6. Sukhaya Termista II, kurgan 1, grave 11. Pared radiocarbon dates of hammer-headed pin and human bone. offset for the pair obtained from the Repin and Yamnaya culture graves (Fig. 4: 6). Dates of terrestrial samples, i.e. horn and wood, and dates of human bone coincide. Other pairs, i.e. human bone and wood, show the offset for the Yamnaya culture no more than 200 years (Shishlina, 2008). However, the size of the offset obtained for other subsequent cultures, i.e. Early Catacomb (Figs. 7 and 8) and Yamnaya-Catacomb (Fig. 9), varies significantly between 184 and 756 years.

An apparent age offset varies due to the variation of climate and the reconstructed diet system (Shishlina

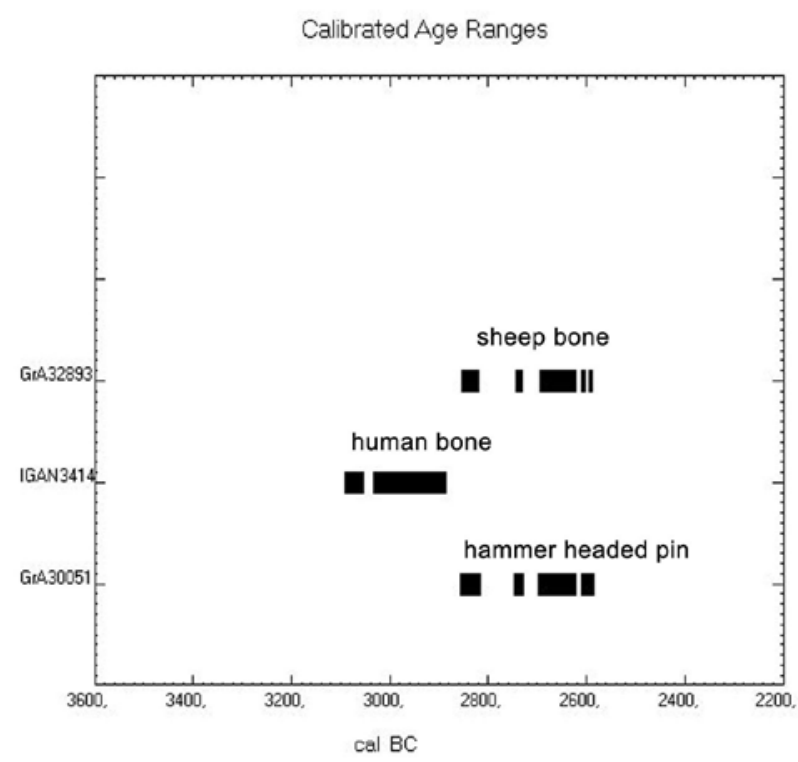

Fig. 7. Temrta V, kurgan 1, grave 3 and 2. Paired dates of hammer headed pins, sheep and human bones.

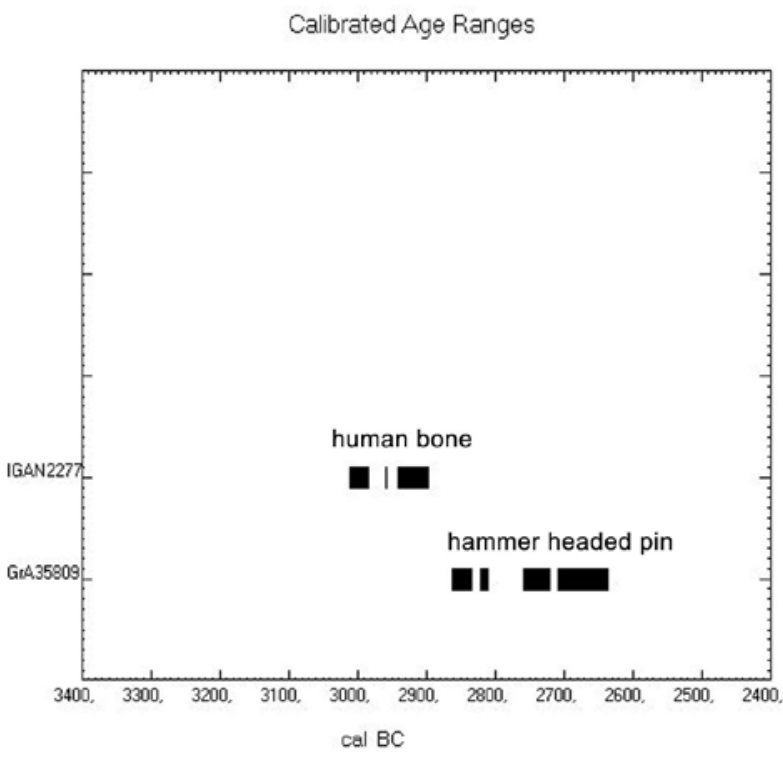

Fig. 8. Mandjikiny-2, kurgan 54, grave 6. Paired dates of hammerheaded pin and human bone. 


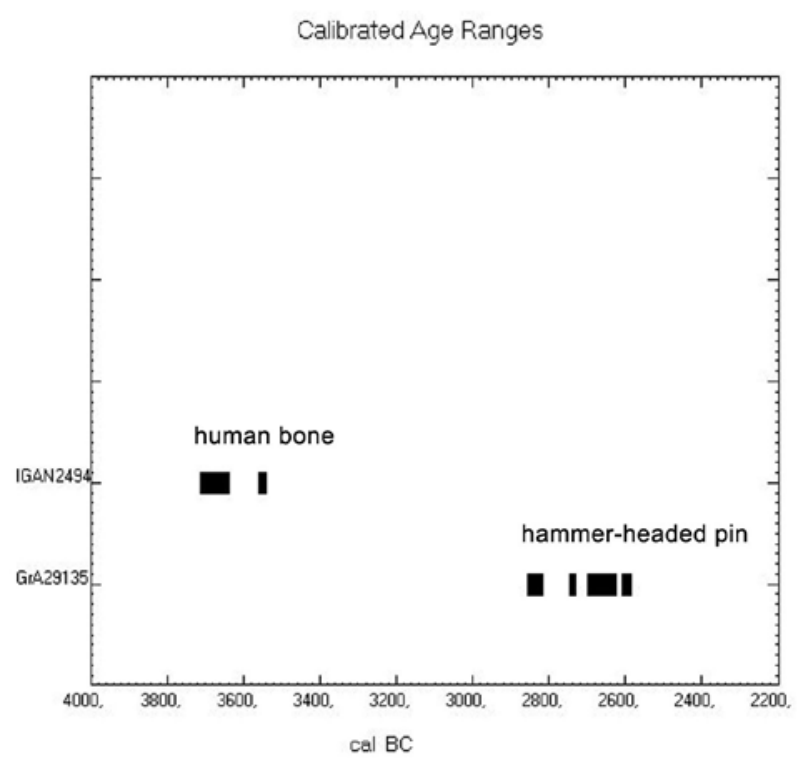

Fig. 9. Zunda-Tolga-5, kurgan 1, grave 7. Paired radiocarbon dates of hammer-headed pin and human bone.

et al., in print). It also becomes evident when we compare dates obtained for human bones and bone pins. An interesting date correlation has been obtained for a primary burial (a pin and a female bone) and a secondary burial from the Temrta burial ground: the ${ }^{14} \mathrm{C}$ age of the pin coincides with the age of the sheep (terrestrial samples nondependent on the reservoir effect), while the date of the female bone is 233 years older (Table 3; Fig. 7). Isotope data confirm the hypothesis that the diet of humans was based on river products (Table 3 ).

\section{CONCLUSIONS}

The presence of bone pins in the graves of Bronze Age steppe cultures implies that probably, they were used during a rather long period and within a rather vast area. Their absence indicates that the production of such pins terminated and they fell out of usage. ${ }^{14} \mathrm{C}$ data obtained help to reconstruct how such pins were used, at least in the cultural environment of the Caspian Steppes linked to the Lower Volga, the Lower Don regions as well as the North Caucasus not only geographically but also culturally.

It is clear that the first pins that appeared on the Steppes were catapult-shaped. ${ }^{14} \mathrm{C}$ date of such items found at Panitskoye 6A confirms this conclusion made by many scholars before the radiocarbon dating was conducted. Such pins are the earliest and they were spread starting from the Repin and Early Yamnaya cultures at the end of $4000 \mathrm{cal}$ BC (Morgunova, 2006).

The population of the Yamnaya culture that inherited Repin traditions (Trifonov, 1996) modernized the pins and a hammer-headed pin appeared starting from 3000 cal $\mathrm{BC}$. When we compare the ${ }^{14} \mathrm{C}$ age of such pins, it turns out that their shape, size as well as the type of ornamentation did not play a significant role, though many scholars consider these characteristics very important. Pins with a later type of ornamentation, according to many classifications (Gey, 2000) are the earliest. Stemshaped pins were used during the same period as ornamented hammer-headed pins with a cylindrical or cigarshaped stem. Trace analyses of bone pins conducted by Usachuk $(2001$; 2002) demonstrate that quite often ornamentation was made in a very sloppy manner by a quick run of a thin metal blade. It is assumed that pins could be the objects of exchange but sometimes family craftsmen made them locally for family use only. Everybody who saw pins knows that each pin is characterized by its own, unique style of decoration, though its elements, i.e. rhombs, triangles, stripes and zigzags, look alike.

Pins were considered to be very special and probably were treated as sacral objects. On the Caspian Steppes they are found quite often in the graves of children and teenagers or women who were very old or of reporoductive age but were placed in male graves on very rare occasions. Usachuk (2002) points out that some pins were used for a very short period because traces of wear are hardly seen. Other pins were used for a very long period. Their surface was very polished and the ornamentation was worn-out. Not only the whole objects but their fragments were used (Usachuk, 2001 and 2002).

This might be the main reason that the date of the pin origin may differ from the date of its placement into the grave. You may see such examples in Table 3.

Finally, how can we define the interval of use of such special items? Data obtained suggest that hammer-headed pins appeared around 3000 cal BC. $2800-2600$ cal BC is the period when such pins were in active use. Moreover, Yamnaya and Early Catacomb population preferred to use such accessories. Yamnaya-Catacomb, North Caucasus populations also used them but not in such great numbers.

After 2600 cal BC pins disappeared. Most likely, this type of accessories went out of fashion, at least in the steppe environment where it was used for special purposes. Indeed, in the latest East Manych culture hammerheaded pins are found very seldom (Kiyashko, 1992).

However, the story presented reflects a special cultural context of only one region, i.e. the Caspian Steppes. The subsequent studies of bone pins uncovered in other regions will help us get an insight as to how and when these beautiful jewelry pieces were used in other cultural traditions.

\section{ACKNOWLEDGEMENT}

This work was done under the support of Russian Fund of Fundamental Research (RFFI), number 08-0600069. 


\section{REFERENCES}

Bratchenko S, 2001. Donetskaya rannekatakombnaya kultura (Donetsk catacomb culture of the Early Stage). Vol. II. Lugansk, Shlyakh: 124pp (In Ukrainian).

Derzhavin VL, 1991. Stepnoye Stavropolie v epokhu rannei i srednei bronzi (The Steppe Stavropol area during the Early and the Middle Bronze Age). Moscow, Nauka: 186pp (In Russian).

Gak EI, 2005. Metalloobrabatyvayuschee proizvodstvo katakombnykh plemen Predkavkazya, Nizhnego Podonya i Severskogo Dontsa (Metal production of the catacomb population of the Piedmont North Caucasus, the Lower Don and the Seversk Donets areas). Moscow: State Moscow University:1-300 (In Russian).

Gey AN, 2000. Novotitorovskaya kultura (Novotitorovka culture). Moscow, Institute of Archaeology: 223pp (In Russian).

Gorodtsov VA, 1915. Kultiry bronzooovoi epokhi v Srednei Rossii (Bronze Age cultures in the Middle Russia). Moscow, Russian Imperial museum: 54pp (In Russian).

Harris EC, 1979. Principles of Archaeological Stratigraphy. London, Academic Press: 185pp.

Kiyashko AV, 1999. Proiskhozdeniye katakombnoi kulturi Nizhnego Povolzia (The origin of the Catacomb Culture of the Lower Don region). Volgograd, Volgograd University Publishing House: 223pp (In Russian).

Kiyashko AV, 2001. O vostochnikh predelakh rasprostraneniya rannekatacombnogo obryada na territorii Volgo-Donskogo mezhdurechya (Eastern boundaries of the Early catacomb funeral rite spreading in the Volga-Don area). In: Sergatskov IV, ed., Materials on Volga-Don Steppe archaeology. Vol. 1. Volgograd, Volgograd State University: 93-109 (In Russian).

Kiyashko VY, 1992. K voprosy o molotochkovidnykh bulavkakh (The hammer-headed pin issue). In: Kiyashko VYa and Maksimov VE, eds., Don Antiquities. Vol. 1. Azov, Azov museum of local lore, history and economy: 4-57 (In Russian).

Kovaleva LG, 1991. Molotochkovidniye bulavki Severnogo Prichernomorya (opyt klassifikatsii) (Hammer-headed pins of the Black Sea region (the classification experience). In: Gavrilov AV, ed., Issues of the Black Sea region archaeology. Kherson: 26-32 (In Russian).

Kozyumenko EV, Bespaly EI, Bespaly GE and Raev BA, 2001. Raskopki kurgannogo mogilnika "Kavkazski-2" (Excavation at Kavkazki-2 burial ground). In: Raev BA, ed., Archaeological survey investigation in Krasnodar region. Krasnodar, Komitet po okchrane, restavratsii i ekspluatatsii istoriko-kulturnykch tsennostey Krasnodarskogo kraya: 155-256.

Latynin BA, 1967. Molotochkovydniye bulavki, ikh kulturnaya atributsiya i datirovka (Hammer-headed pins, their cultural attributions and dating). Leningrad, Iskusstvo. Archaeological Bulletin of the Hermitage Museum: 9. (In Russian).

Mimokhod RA, 2009. Kurgans of Bronze Age - Early Iron Age in the Saratov Trance-Volga region: characteristic and cultural attribution. Moscow: Institute of Archaeology RAS: 290pp (In Russian).

Morgunova NL, 2006. Osobennosti kostyanykh "bulavok" yamnoi kultyri Priuralia (Peculiarities of bone "pins" of the Yamnaya culture of the Ural region). Nalchik, OOO "Institut archeologii Kavkaza". XXIV Krupnov Reedings on the North Caucasus Archaeology: 135-138.

Plicht van der J, Shishlina NI, Hedges REM, Zazovskaya EP, Sevastyanov VS and Chichagova OA, 2007. Reservuarny effect i radiouglerodnaya khronologia katakombnych kultur Severozapadnogo Prikaspia (Reservoir effect and results of 14C Dating of Catacomb cultures of the North-West Caspian Steppe Area: a case study). Russian Archaeology 2: 39-47 (In Russian).

Porokhova OI, 1992. Gerasimovski kurganni mogilnik v Orenburgskoi oblasti (Gerasimovka kurgan burial ground in the Orenburg region). Orenburg: Orenburg Pedagogical Institute. Ancient history of the Volga-Ural region population: 14-21 (In Russian).

Reimer PJ, Baillie MGL, Bard E, Bayliss A, Beck JW, Bertrand C, Blackwell PG, Buck CE, Burr G, Cutler KB, Damon PE, Edwards RL, Fairbanks RG, Friedrich M, Guilderson TP, Hughen KA, Kromer B, McCormac FG, Manning S, Bronk Ramsey C, Reimer RW, Remmele S, Southon JR, Stuiver M, Talamo S, Taylor FW, van der Plicht J and Weyhenmeyer CE, 2009. IntCal09 and Marine09 radiocarbon age calibration curves, $0-50,000$ years cal BP. Radiocarbon 51(4): 1111-1150.

Safronov VA, 1973. Klassifikatsiya predkavkazskikh kostyanykh molotochkovidnykh bulavok (The classification of Piedmont North Caucasus bone hammer-headed pins). Kratkiye soobscheniya instituta arkheologii 134: $42-47$ (In Russian).

Sherrat A, 1997. Troy, Majkop, Altyn Depe: Early Bronze Age Urbanism and its Periphery. In: Sherrat A, ed., Econome and Society in Prehistoric Europe. Changing Perspectives. Cammridge: Edinburg University Press: 457-470.

Shishlina NI, 1992. Ranni etap srednei bronzi Kalmykii (Early Stage of the Middle Bronze Age in Kalmykia). Ph.D. Dissertation. Moscow, Institute of Archaeology Russian Academy of Sciences: 238pp (In Russian).

Shishlina N, 2008. Reconstruction of the Bronze Age of the Caspian Steppes. Life styles and life ways of pastoral nomads. BAR International Series 1876: 299pp.

Shishlina NI, Zazovskaya EP, van der Plicht J, Hedges REM, Sevastyanov VS and Chichagova OA, 2009. Paleoecology, Subsistence and ${ }^{14} \mathrm{C}$ Chronology of the Eurasian Caspian Steppe Bronze Age. Radiocarbon 51(2): 481-500

Shishlina NI, Sevastyanov VS and Hedges REM, in print. Isotope Ratio Study of Bronze Age samples from the Eurasian Caspian Steppe.

Smirnov AM, 1996. Kurgany i katakomby epokhi bronzy na Severskom Dontse (Bronze Age kurgans and catacombs of the North Donets area). Moscow: Institute of Archaeology: 181pp (In Russian).

Tkachev VV, 2000. O yugo-zapadnikch svyazach naseleniya Yuzhnogo Urala v epokhu rannei I srednei bronzi (South-west links of Southern Ural population during the Early and Middle Bronze Age). In: Tkachev VV, ed., Problems of the investigation of the Eneolithic and Bronze Age of the Southern Ural region. Orsk, Institute of Eurasian investigation: 37-65 (In Russian).

Trifonov VA, 1996. Repinskaya kultura i protsess slozheniya yamnoy kulturno-istoricheskoy obschnosti (The Repin culture and the process of Yamnaya culture origin). In: Kiyashko AV, ed., Antiquities of the Volga-Don steppes in the East Europe Bronze Age system. Volgograd, Peremena: 3-5 (In Russian).

Usachuk AN, 2001. Resultaty trassologicheskogo analiza kostyanykh izdeliy iz pogrebeniy kurgannykh mogilnikov yuga Kalmykii (Results of traceware analysis of bone goods from graves of kurgan burial grounds of Southern Kalmykia). In: Tsutskin EV and Shishlina NI, eds., Mu-Sharet kurgan burial grounds in Kalmykia: interdisciplinary investigation. Moscow-Elista, State Historical Museum: 74-80 (In Russian).

Usachuk AN, 2002. Kostyaniye izdeliya kurgannikch mogilnikov Kalmikii (trassologicheski analiz) (Bone items from Kalmykia kurgan burial grounds (traceware analyses). In: Tsutskin EV and Shishlina NI, eds., Ostrovnoy kurgan burial ground. Results of interdisciplinary investigation of Northwestern Caspian archaeological sites. Moscow-Elista, State Historical Museum: 267-279 (In Russian). 